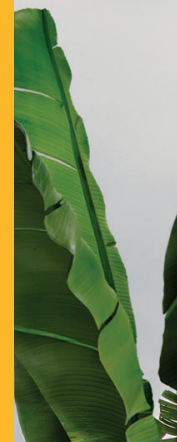

The Journal

\section{of the}

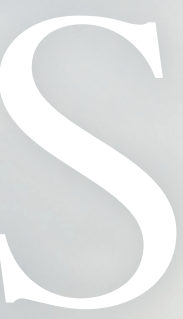

VOLUME 128 No.3 SEPTEMBER 2019

THE POLYNESIAN SOCIETY THE UNIVERSITY OF AUCKLAND NEW ZEALAND

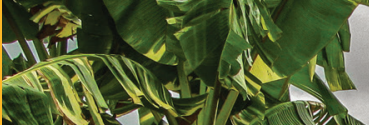

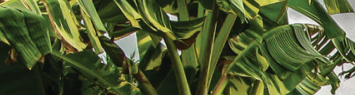

$3 x^{3}$

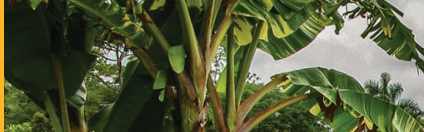

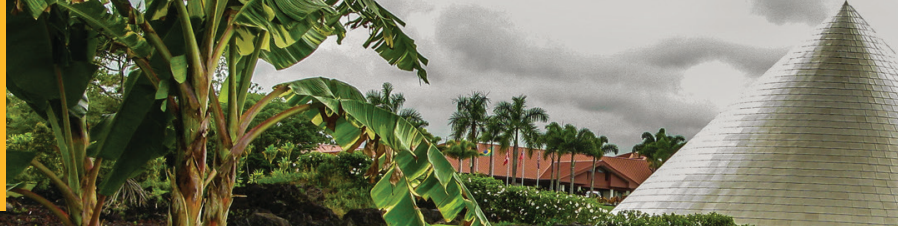

(6)

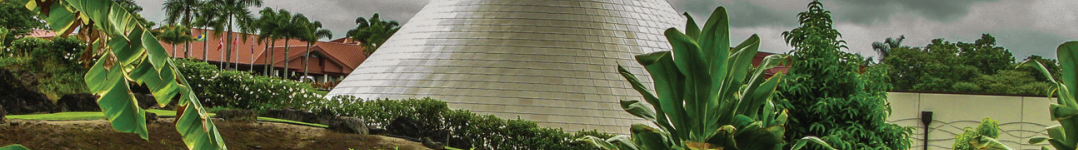

$1012(12)=0$

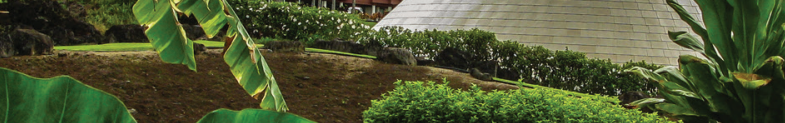

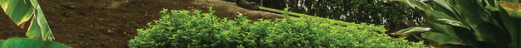

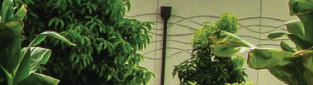

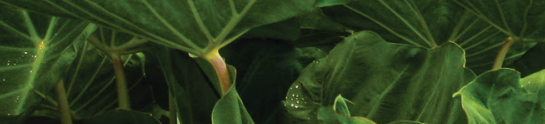




\title{
LIFE AND DEATH OF AN EGG HUNTER: PROPOSAL FOR A REINTERPRETATION OF A RAPA NUI (EASTER ISLAND) STRING FIGURE CHANT
}

\author{
MARY DE LAAT \\ Independent Researcher
}

\begin{abstract}
Pre-missionary Rapa Nui (Easter Island) literature has only survived in a small corpus of poorly understood recitations. Their obscurity has been attributed to the disappearance of the old culture as a result of the catastrophic decline of the native population in the second half of the nineteenth century and the considerable change that the Rapanui language has undergone under the influence of other languages. A similar judgement has been passed on one of the most popular songs in the traditional repertoire, a string figure chant that was recorded in the twentieth century by several anthropologists, among them Routledge in 1914 and Métraux in 1934-1935. A complete version of the chant was first published in 1960 by Barthel. However, his uneven translation takes many liberties with the original text and leaves much unexplained. Barthel's idea that the chant's main topic is the burial of a man who once held the important ritual position of "birdman" has nevertheless been generally accepted by subsequent researchers. Fortunately, since then the unpublished fieldnotes of both Routledge and Métraux have become available. Despite the fact that they reveal that already in the first half of the twentieth century the chant's meaning could no longer be explained by the native informants, they shed light on a number of cryptic passages by providing important material for comparison and reconstruction. This has made it possible to propose in this study an alternative interpretation of the text as a lyrical account of the death of a hopu manu, a contender in the annual competition for the sacred bird egg to select the new birdman. If this proves to be correct, the chant would constitute a unique example of early Rapanui poetry, an intriguing artefact of the enigmatic birdman cult and an incentive for further research into texts that have been written off as too archaic and obscure.
\end{abstract}

Keywords: Rapanui language, Rapa Nui (Easter Island), birdman cult, Orongo, string figure chant, kaikai

The lifeless body of a young man is lying at the foot of the foreboding cliffs lining the southwestern shore of Rapa Nui (Easter Island). He has fallen to his death in an attempt to climb the $300 \mathrm{~m}$ high rock wall that forms part of the extinct volcano Rano Kau. On top of the narrow crater rim perches the ceremonial village of Orongo - his destination. In pre-missionary times, this group of stone houses amidst elaborately sculptured rocks hosted the annual 
competition to establish who would take up the ritual position of tayata manu 'birdman' for the year to come. The cult of the birdman disappeared along with much of the rest of the old culture in the 1860 s, a period in which the population of Rapa Nui was decimated by slave raids and imported diseases.

Most of our information on the enigmatic rite was collected by Thomson (1891: 482-83) and Routledge (1919: 254-66). At the beginning of the austral spring, contestants from the elite or their proxies descended the cliff, swam to the tiny offshore islet of Motu Nui and awaited there the arrival of the birds. Initially, the object of their desire appears to have been the egg of the makohe, the sacred frigatebird. After this bird stopped nesting there, it was replaced by the egg of the manu tara, the sooty tern. Once the first egg was procured the winner had to undertake the hazardous return trip. Again he had to overcome the strong ocean currents, the sharks, the dangerous coastal rocks and the steep cliff.

According to tradition, the possession of the egg made the finder impervious to all these perils, but it seems more likely that whoever was the first to return to Orongo with an egg intact was declared victor. He would then either become the next birdman or-if he was a stand-in - present the precious object to his patron. After the celebrations, the new birdman would spend a year in isolation surrounded by many taboos. Some have suggested that through the acquisition of the egg the supreme god Makemake incarnated in the birdman thereby ensuring a year of plenty (e.g., Métraux 1940: 335).

The unfortunate climber whose body is lying on the narrow strip of rocks behind the turmoil of the roaring breakers of the Pacific Ocean was one of these proxies for the elite, called hopu or hopu manu. The story of his tragic demise is told in a kaikai-a type of traditional chant that is performed accompanied by string figures. The first part of the song tells of his ill-fated return journey - the injuries he sustained from the aggressive seabirds and the jagged rocks surrounding the three offshore islets, Motu Kaokao, Motu Iti and Motu Nui, and the ultimate failure to reach the sculptured rocks of Orongo. The second part fondly reminisces on the life he is leaving behind-the family home, the parents with their daily occupations and the girls he loved. The uniqueness of this particular text lies in the fact that these recollections seem to be told from the perspective of the victim. Taking into account the Polynesian dualistic notion that the soul can function independently of its corporeal receptacle, it can therefore be hypothesised that we are hearing the voice of the young man's spirit as it is in the process of departing from the body or lingering nearby after having done so.

To be clear, this is not how this kaikai chant has been interpreted by scholars of Rapanui culture. On the contrary, their translations suggest that it is an incoherent and in many parts obscure narrative. It is this paper's aim to tentatively propose an alternative to this generally accepted view. 


\section{LOSS OF MEANING}

The most important research into the oral traditions of Rapa Nui was undertaken in the second half of the nineteenth and the first half of the twentieth centuries by William Thomson, Katherine Routledge, Alfred Métraux and Sebastian Englert. Unfortunately, by that time the premissionary culture had suffered immensely from the impact of slave raids, diseases, foreign languages and conversion to Catholicism. This is reflected especially in the corpus of Rapanui chants that were recorded in sessions with native informants. Although Rapanui were able to produce a significant body of texts from memory, it is clear that many of these were only poorly understood by them. The publications of Thomson and the fieldnotes of Routledge and Métraux amply show that in most cases their informants had to limit themselves to speculations about the subject matter and explanations of isolated words. For example, when inquiring about He timo te akoako, a widely known but obscure text that was associated with the enigmatic rongorongo script, Routledge observed:

To get any sort of translation was a difficult matter, to ask for it was much the same as for a stranger solemnly to inquire the meaning of some of our own old nursery rhymes, such as "Hey diddle diddle, the cat and the fiddle"words could be explained, others could not, the whole meaning was unknown. (Routledge 1919: 248)

Several explanations have been offered for the difficulty of obtaining a meaningful translation from the native population. It has been suggested that the traditional chants contain many remnants of the ancient language (sometimes called Old Rapanui) which differed very much from the post-missionary-i.e., post-1864-idiom that had rapidly changed under Mangarevan, Tahitian and European influences. It has also been assumed that the texts' inaccessibility was the result of their being steeped in esoteric knowledge which could only be understood by the initiate and which had disappeared along with the ancient system of belief. All this has led to a general pessimism regarding the possibility of understanding many of the traditional Rapanui chants: "Pictorial and abbreviated locutions, ambiguities and the occurrence of archaic expressions, but in part also a gradual loss of meaning, stand in the way of a really satisfactory translation" (Barthel 1960: 842). ${ }^{1}$

To evaluate these claims for the corpus as a whole is not possible in the short space of an article. However, some conclusions can be drawn from the study of the chant that is presented here as it has confronted the various interpreters with a number of the problems raised. Although its language does not give the impression of being very archaic or esoteric, it is apparent that it 
had been performed for a considerable time without a clear understanding of its meaning. This suggests that - at least in this particular case - the difficulties encountered may have had a different origin.

\section{VERSIONS}

The earliest version of the chant is found in the unpublished fieldnotes of Routledge (1914-15: Reel 2, 0683-84), who stayed on Rapa Nui from March 1914 until August 1915. Her notes are headed by the text "cat's cradle kai kai" and a rough sketch of a string figure. The labels "wing" and "tail" suggest that the figure is representing a bird. In the transcription below, the Rapanui text has been italicised. Routledge's glosses - originally placed under the Rapanui words - have been inserted and marked by square brackets. The (added) ellipses indicate where she interrupted the text of the chant with some remarks about the session.

ka me mea [red] no | tó koro [father] hami ["fig leaf"] méa [red] | táve ke ituai [it is a long time] itu ohiro [? moon] ká u úri nó [it is black] | tó koró [cry] tangáte [men] | itua [old] ohiro [moon] | kavária tágne nó [there is much crying] | ma haki [will cry] té makoi [a white bird] párigni te mátavái [tears] | o te túavi [a bird] | kariti [streams] te hupé [nostrils] | o te kúkúru toua - evé pépé-pépé aúré | motu nui | étúru [3] agnérá [times] | ka kai to kóro pero | motu iti [motu iti] motu nui [motu nui] motu kákáo [motu kakao] | kai ta ui mai koe [you will not see] ma púku rákeráke vae [foot] é pau éra [turned in] ki te aku papaku [corpse] | hé úha [hen] kúri [cat] ta pápákúri uha [hen] méa [red] iti iti [little] totehátá uma [(not known)] he ngau ngau no [a wood wh. smells] ta puku [(repetition)] ngau ngau [wood wh. smells] he orongno tapuku [repetition] orong ... he orongo noa ta o rongorongo

Routledge gives "Parapina" and "Antonio" as the names of her sources and "Henry" as her translator. According to Van Tilburg (2003: 146; 285), they were the natives Antonio Haoa Pakomio, his wife Parapina Araki Bornier and expedition member Henry MacLean who served as English-Spanish translator. The session must have taken place sometime before 14 August 1914 as on that day MacLean left the island (Van Tilburg 2003: 163).

Routledge's glosses clearly indicate that by this time the general meaning of the text was no longer understood. The informants resorted to explaining individual terms and did not provide a single complete sentence. Routledge also suspected that they avoided clarifying certain terms that they deemed inappropriate. One of these, evé 'buttocks', she marked as such. Apparently, she did not undertake a further attempt to elicit a translation of the chant. Although her fieldnotes were deposited at the Royal Geographical Society in London, they were long thought of as lost. As they did not resurface until 1975 (McCall 2006: 251-52), this important version has long been unavailable to subsequent researchers. 
The next explorer to mention the chant is Brown, who visited the island in 1922 and also saw it performed accompanied by string figures. Unfortunately, he only published the first eight verses as "Kami mea no, to koro hami mea, tara ke tu aere, Kamiri no, to koro tangata tuao iti Ohiro, karave tangi noa mahaki ke makohe, etc.", commenting: "It was evidently the frigate-bird and his deeds that supplied the subject of the song; and further on in the song the bird islands, Motunui, Motuiti, and Raukau [sic] are introduced and the scene of the bird-watching, Orongo" (Brown 1924: 205). Brown also gives a description of one of the accompanying kaikai figures, called "the bird", which may have resembled the one drawn by Routledge.

During the Franco-Belgian expedition of 1934-1935, Métraux (1934-35, NB 3: 2-4; NB 5rb: 8-10) collected two versions of the chant, one some 11 verses longer than Routledge's, the other with some 22 additional verses. Apparently, Métraux did not feel very comfortable with the material as he did not attempt to translate the complete text. In his monograph Ethnology of Easter Island, he published a mere four verses from the middle part, referring to it as "an old chant" (Métraux 1940: 137):

He naunau no ta Puku-naunau. He rongo-rongo no ta Orongo.

He tahonga no ta Puku-tahonga. He kiakia no ta Puku-kiakia.
There is a sandalwood tree in Puku-naunau. There is a chanter at Orongo.

There is an expert craftsman in Puku-tahonga. There is a kiakia bird on Puku-kiakia.

To make sense of these verses, Métraux (1940: 136) assumed that the term tahonga is connected to Polynesian tahunga 'expert'. His fieldnotes show that he also changed a word in the second line which had originally been recorded as "he oroyo no ta oroyoroyo" (Métraux 1934-35, NB 5rb: 9).

More than twenty years later, sometime between July 1957 and February 1958, Barthel recorded another version of the song, one that was apparently very similar to Métraux's second version. He was the first to publish the integral text and an annotated translation (Barthel 1960: 854-56). Barthel (p. 842) had Métraux's fieldnotes in his possession and he states that he used them to clarify some obscure passages. Unfortunately, he gives no further details regarding the text he himself collected or which problems were solved by Métraux's notes. It is, however, clear that his translation is in close agreement with the glosses provided by Métraux.

Since the chant mentions a death taboo and a corpse, Barthel interprets it as a description of a funeral ceremony [Totenfest]. The presence of birds - among them the frigatebird - and locations at the southwestern tip of the island such as Orongo lead him to believe that the deceased has been a birdman during his lifetime. He also points to two traditions which link the sandalwood and the two hens that are mentioned in the text to the birdman cult: a piece of this wood was fastened to the arm of the victor of the egg race, and during 
the funeral ceremony for a birdman five cocks were tied to each leg of the deceased. Additionally, he suggests that there is an initiation motif in the chant as other sources mention tahoya hangers and the dance called hikiga kauya in connection with children's coming-of-age rites.

The Rapanui text as published by Barthel is presented here with a retranslation of his German translation. The markers //: and :// surrounding lines 13-14 indicate repetition. The question marks in lines 14 and 26 are also in the original.

ka memea no

to koro hami mea

tavake i tua e

ka uuri no

5 to koro tangata

tuao $i$ te ohiro

ka rava tangi no

mahaki te makohe

ka riti te hupee

10 o te kukuru toua

eve pepepepe

a ure motu nui

//: etoru ange ra ://

//: ka kai to koro pera ://

15 motu nui

motu iti

motu kaokao

kai tuu mai koe

e papa rona

20 rakerake era e

vae pau era e

ki taaku papaku

he uha uri

ta papaku uri

25 uha mea itiiti

to te hatauma

he naunau no

ta puku naunau

he orongo no

30 ta orongorongo

he retu no

ta hu hatu retu

he tahonga no

ta puku tahonga
How red

the painted loincloths at the feast are

the tavake bird on the backside

How black

the men at the feast are

the tuao bird in Te Ohiro

How bitterly weeps

the younger sister, the frigatebird

How it streams - while crying - from the

nose

of the yellowish kukuru bird

with the very short tail

from Ure-Motu-Nui

What a food at the funeral feast (?)

Motu Nui

Motu Iti

Motu Kaokao

You will not come-

o rock with relief figures,

where there is evil

and where there are clubfeet-

to my corpse

A black hen

belongs to a dark corpse

A very small red hen

belongs to the corpse lying in state (?)

A single sandalwood tree

belongs to Puku Naunau

A single tattoo on the forehead belongs to the group of tattoo experts

A single wooden hanger

belongs to Puku Tahonga 
35 he kiakia no

ta puku kiakia

to koro vaka tere

ko haho ko vai vaka

ta koro paoa mau

40 ko vai paoa oa

ta koro toa rei

ko te ngaatu a hurirenga

ka huhuti

to koro hare moe

45 ko raro ko te paenga

to koro papa hiki kaunga

ko runga ko papa rona

ta koro тапи таu

ko te vai hopu manu

50 ta nua heke too

ko haho ko koro heke

ta nua hetuke tunu

ko vai hetuke tunu

ta nua kumara keri

55 ko te pua a hurirenga

ta пиа ити ka

ko te ehuehu

ko te kapuapua
A single white tern

belongs to Puku Kiakia

To father who fishes in his boat

belongs Vai Kava out there

To father who grabs the club

belongs Vai Paoa Oa

To father who breaks the sugarcane

belong the rushes of Huri Renga

Pull them out!

To father who sleeps in the house

belong the foundations below

To father who dances on the rocks

belong the sculptured rocks above

To father who grabs the bird

belongs Vai Hopu Manu

To mother who catches the octopus

belongs Koro Heke out there

To mother who cooks the sea urchin

belongs Vai Hetuke Tunu

To mother who digs up the sweet potatoes

belongs the yellow root of Huri Renga

To mother who lights the earth oven

belongs the grey smoke

belongs the fog

Apart from the two segments Barthel left untranslated, his interpretation has several other problematic aspects. In the first lines, the presence of the different birds gives rise to incoherent and implausible sentences. Particularly odd are the notions that birds would weep with runny noses for a deceased birdman and that a rock would come to a corpse. Why there would be "clubfeet" involved is also left unexplained. For a number of translations such as "sister" for māhaki and "group of tattoo experts" for hatu retu, no justification can be found in the vocabularies.

As can be learned from the fieldnotes of Routledge and Métraux, their informants showed a strong tendency to explain unknown words or passages as proper names of persons, gods and places. In the case at hand, Barthel has accepted this uncritically. As a result, his interpretation of the second part of the text in particular relies heavily on unattested toponyms. By his own admission, Barthel (1960: 856) considerably changed the order of the verses in the second part: "We have arranged the paired verses from the three text variants at our disposal according to the keywords koro and nua, respectively." He remarks that the original order may have alternated between the activities of the father and mother. Although he does not motivate this reorganisation 
into a strict father-mother division, it can be accepted as it makes the text more coherent and does not influence the interpretation.

After Barthel, at least three additional versions were published accompanied by a translation. Campbell (1971: 403-6) recorded words and music in 1966 from Amelia Tepano, describing it as a "rhythmic recitative" more than 100 years of age. Unfortunately, his "free translation" reduces most of the text to nonsense.

The translation by Felbermayer (1972: 277-79) is almost as problematic. His version has an additional 13 lines at the end of the text. These have apparently been created in more recent times based on the interpretation of the chant as a description of a funeral ceremony. Possibly, they were added to clarify some of its obscurities. It says, for example, Ka oho de [sic] Kuhane o koro o oku ki Havaiki 'Let the spirit of my father go to Havaiki'. However, in the older sources on Rapa Nui, Havaiki - or Hawaiki-is not found as a name for the ancestral homeland or the spiritual afterworld. Yet another version was published by Blixen (1979: 90-98) in his study of Rapa Nui string figures. Apart from the marking of the glottal stop, his Rapanui text is largely in agreement with Barthel's publication, as is his translation.

It will not be necessary to discuss the last three translations in greater detail as they add little to the understanding of the text. The reconstruction and interpretation of the chant presented here have been based primarily on a comparison of the versions of Routledge, Métraux and Barthel. Some of the string figures provided by Routledge, Campbell, Felbermayer and Blixen represent objects mentioned in the chant - such as a bird and a boat - but most of them lack recognisable features. They also contribute no additional information and will not be further examined here.

\section{REINTERPRETATION}

Barthel's translation suggests that the chant is confused and in part obscure. However, a few minor adjustments in the text and a different interpretation of some of its keywords turn it into an intelligible and coherent narrative. The fieldnotes of Routledge - which were unavailable to Métraux and Barthelcan be used to clear up a number of problematic passages.

One of the terms that has caused problems is koro, a word that is used in different meanings. In one instance, Routledge glosses it, inexplicably, as 'cry'; in another it is left untranslated. To Métraux, the occurrences in the first part of the chant were explained as 'papa' and 'fiesta', in the second part as 'padre'. Barthel assumed that the word was used in the first part as 'feast' and in the second part as 'father'. This division works well for the interpretation of the text. The "feast" is interpreted by Barthel as a funeral ceremony for 
this "father", who is assumed to have been a birdman. The second part of the chant is supposed to describe the activities of the deceased and his wife.

The most important reason for the assignment of these roles appears to be the phrase taaku papaku 'my corpse' in line 22. In Rapanui, as in other Polynesian languages, the body and the body parts are typically $o$-possessed (Mulloy and Rapu 1977: 13). Mulloy and Rapu define the $o$-class as marking "a possession which is responsible for its owner, one upon which the owner is dependent", whereas the " $a$-class that is used here marks "a possession for which the owner is responsible, one which is dependent upon its owner" (p. 8). More recently, Kieviet has suggested that $o$ is actually the default possessive marker while " $a$ is only used when the possessor is dominant and/or active in relation to the possessee" (2017: 311). Presumably, the use of the ' $a$-possessive pronoun in this phrase has led Barthel (and others) to rule out the possibility that pronoun and noun refer to the same person and to assume that the possessor is someone who has the responsibility of taking care of the corpse. There is, however, an alternative explanation possible if the traditional belief system is taken into account:

As everywhere else in Polynesia, the underlying idea of the Rapanui theogony was that of the tangata 'living human being' as a dichotomy of hakari 'body' and kuhane 'soul'. It was believed that the kuhane left the hakari at the death of the person, surviving it to lead an independent human life and preserving all characteristics and abilities of the former living person, in addition acquiring the capability to adopt any shape, including that of the former living person. (Bierbach and Cain 1993: 135)

In this conception, a spirit that is leaving a deceased person could be held responsible for the transformation of the living body into a corpse and could therefore be regarded as the initiator of the possessive relationship. If it is assumed that the voice we are hearing is that of the spirit of the hapless egg hunter that is detaching itself from the body - or, having done so, is still lingering nearby - it would explain the fact that "my corpse" is " $a$-possessed.

Moreover, if the chant as a whole is interpreted as a reflection of the spirit on the young man's death in the context of the birdman ritual and on his past family life, other puzzling pieces of the text start to fall into place. Most importantly, the change of perspective makes it possible to account for the way other items are distinguished as alienable $(t a)$ or inalienable $(t o)$.

The forms $t a$ and $t o$ 'that of' are contractions of the article $t e+$ possessive prepositions ' $a$ and $o$, respectively, and survive in modern Rapanui mainly in a series of possessive pronouns. In Barthel's interpretation, however, the choices for either $t a$ or to make little sense. In lines 23-26, for example, the possessive relations of the "black hen" (marked as $t a$ ) and the "little red hen" (marked 
as to) are interpreted as grammatically identical. In addition, certain rocks are named as places to which - for some unexplained reason-items such as a tahoya pendant and a white tern "belong". It seems unlikely that these objects were marked as " $a$-possession to signal an "active" or "dominant" role on the part of their stony "possessors". If, on the other hand, it is assumed that the young man's death has been caused by these boulders and that his body and belongings in time will become part of them, this would imply a much more active role of these rocks.

In the second part of the chant, a similar situation is encountered. In Barthel's interpretation, a number of water bodies are mentioned as "belonging" to the father or the mother. Without an apparent difference in function, these are either marked by a ta- or a to-possessive. However, if the interpretation of these locations as belonging to certain persons was correct, they would more likely be $o$-possessed (see Mulloy and Rapu 1977: 13; Kieviet 2017: 292). Furthermore, the lines structured as "to father/mother doing X, belongs ko te Vai X" seem very awkward. If these indeed were existing bodies of water, they would more likely be named "Vai X", and therefore the expected phrase with the marker would be "ko Vai X". However, if the phrase ko te vai is read as ko te va' $a i$, i.e., as a nominalisation of the verb $v a$ ' $a i$ 'to give', this would produce a series of plausible sentences. It is therefore proposed that in this text ko te + verbal noun constructions are used to indicate habitual action. To be sure, this is different from modern Rapanui where "[t]he construction ko te + verb signifies that an action or situation is ongoing or persisting" (Kieviet 2017: 91).

An additional problem posed by the proper names of the "rocks" and "waters" is that they are not mentioned in other sources. As will be demonstrated below, a different interpretation not only does away with these fictitious toponyms but also satisfactorily explains the use of the possessives $t a$ and to according the grammatical rules concerning the alienable-inalienable dichotomy: marked for ' $a$-possession are the tasks of the father (carrying a club; crushing sugarcane; carrying the birdman) and the mother (digging up potatoes; catching octopus; lighting the earth oven; cooking sea urchins); marked for $o$-possession are the house, the boat and the loincloth. This leaves only the inalienable marking of the "dancing on the rocks" as somewhat problematic.

\section{RECONSTRUCTION AND RETRANSLATION}

The text as published by Barthel requires only minor adjustments to be transformed into a coherent and intelligible text. The reconstruction below follows his rearrangement of the second part of the chant. No attempt has been made to fit the material into some hypothetical metrical scheme. Given the 
shortcomings of the source material—Routledge and Métraux, for example, often differ in their marking of stress - this would have been a fruitless exercise. The modern musical performance, typified by Campbell (1971: 405) as "irregular", also fails to provide any clues in this respect.

The text has been adapted as much as possible to modern orthography. Glottal stops and vowel length have been marked in so far as reliable sources were available. The marking of the latter, however, is not to be taken as an indication of how the performance actually sounded as vowels tend to be freely shortened or stretched in chants. The repetition of lines 14-15, 28-30, 39 and 43 in some of the sources has been ignored.

ka memea $n \bar{o}$

to koro hami mea

tava kē 'i tu'a i te 'ōhiro

ka u'uri nō

5 to koro tayata

'i tu'a i te 'ōhiro

ka vara tayi nō

māhaki te makohe

parini te matavai 'o te tu'aivi

10 kari i te hope

o te kukuru toua

eve pe'epe'e

pe'epe'e 'à ure motu nui

etoru haye rā

15 ka kai to koro pera

motu nui

motu 'iti

motu kaokao

kai tu'u mai koe

20 e papa rona rakerake $\bar{e}$

vae pahu era e

ki tā'aku papaku

he uha 'uri

ta papaku 'uri

25 uha mea 'iti' 'iti

to te 'ata ōma

he naunau nō

ta puku naunau

he 'ôroyo nō
How brightly coloured (it) is, the red loincloth of the ritual, (and) how pale (he) is, (lying) behind the turbulent surf.

How bruised (he) is, the man that took part in the ritual, (lying) behind the turbulent surf. How (it) keeps on screeching, (his) companion, the frigatebird!

(He) has shed tears on account of (his) back as (it) scratched (his) spine.

And because of the kukuru toua bird, (his) buttocks were badly injured, while (his) penis was maltreated by Motu Nui. But (he) got the better of those three!

How sharp (they) were, the graveyards of the ritual:

Motu Nui,

Motu Iti

and Motu Kaokao.

But you (he) could not reach, wretched sculptured rock!

(You) have chosen the "coffin"

for my dead body!

There was a dark-skinned girl

that belonged to this bruised corpse, and a little fair-skinned girl that belonged to this disfleshed "shadow". (Now) there are only sandalwood trees, (he) will be part of the rocks with the sandalwood trees.

(Now) there is only Orongo, 
30 ta puku 'ōroyo

he 'ōroyo nō

ta royo o 'ōroyo

he retu $n \bar{o}$

ta hü hatu retu

35 he tahoya nō

ta puku tahoya

he kiakia nō

ta puku kiakia

to koro vaka tere

40 ko haho ko te va' ai vaka

ta koro pāoa mau

ko te va'ai pāoa oa

ta koro toa rei

ko te yatu 'ā huri reya

45 ka huhuti

to koro hare moe

ko raro ko te paeya

ta koro papa hiki kauja

ko ruya ko papa rona

50 ta koro manu mau

ko te va' ai hopu manu

ta nua kumara keri

ko te pua 'à huri reya

ta nua heke to 'o

55 ko haho koro heke

ta nua hetuke tunu

ko te va' ai hetuke tunu

ta nua umu ka

ko te ehuehu

60 ko te kapuapua (he) will be part of the rocks of Orongo.

(Now) there is only Orongo,

(he) will be part of the tales about Orongo.

(He) has a single tattoo on the forehead,

(it) will be part of these "tattooed" boulders.

(He) has a single tahoya pendant,

(it) will be part of these egg-shaped boulders.

(Now) there are only these white terns,

(he) will be part of these rocks with (their)

white terns.

Taking the boat out was (his) father's job, (but) out at sea (he) would let (him) have (control of) the boat.

Carrying a club was father's job, (he) would let (him) have that club! Ouch! Crushing sugarcane was father's work.

(He) planted the yellow shoots and then (he) pulled out the weeds.

The house (he) slept in belonged to father, the paeya stones were the foundation.

Dancing with flexed knees in a line was father's task,

on top of that sculptured rock.

Carrying the birdman was father's task, (he) provided (him) with a proxy!

Digging up sweet potatoes was mother's work, (she) covered up the yellow shoots.

Catching octopus was mother's work, (she) was out there when there were octopuses. Cooking sea urchins was mother's work, (she) served (him) those cooked sea urchins. Lighting the earth oven was mother's work,

(it) produced a thick smoke,

(it) produced a dense fog.

\section{Commentary}

Where relevant, the alternative lines of the source texts are cited. They are referred to as R (Routledge 1914-15, Reel 2: 0683-84); Br (Brown 1924: 205); M1 (Métraux 1934-35, NB 3: 2-4); M2 (Métraux 1934-35, NB 5rb: 8-10); Ba (Barthel 1960: 854-56). In R and M1, stress is usually marked with an acute accent on the vowel. In M1, short vowels are occasionally indicated with a breve.

1) ka memea nō: Likely, the redness of the loincloth also refers to the blood covering the victim's body. 
2) to koro hami mea: The fact that the birdman ritual is marked as possessor of the loincloth suggests that the competitors were wearing ceremonial dress.

3) tava kē 'i tu'a i te 'óhiro (R: táve ke ituai itu ohiro; Br: tara ke tu aere; M1: távăkě i túă e; M2: tavaké i tua e; Ba: tavake i tua e): In R, the first two words are not glossed; in M2 they are glossed as 'otro lado', i.e., read as taha ke 'other side'. M1 and Ba interpret tavake as a bird name, which may have been inspired by the mentioning of the colour red in the previous verse and the presence of two other seabirds - the makohe and the kukuru toua - in the lines that follow. On Rapa Nui, tavake was the name of the red-tailed tropicbird (Phaethon rubricauda). Its elongated red tail feathers were in high demand for ornamental usage (Englert 1978: 261). However, the fact that in $\mathrm{R}$ it is written as two words and that in the metrical notation of R, M1 and M2 not the expected second syllable but the first or third are marked for stress makes this interpretation questionable. This gives room to the alternative possibility that the first part is the short form of tavatava 'pale' (Englert 1978: 261), followed by ke 'different'. In this way, the bright red colour of the loincloth is contrasted with the pale complexion of the deceased.

Because of the absence of ohiro in M1, M2 and Ba, the complex preposition ' $i$ tua $i$ was turned into $i$ tua e, i.e., tua became interpreted as a noun. This has led to awkward translations such as Barthel's "the tavake bird on the backside".

To Routledge the word ohiro was explained as 'moon' since Ohiro was the name of the night of the new moon. However, as "behind the new moon" fails to make much sense, it can be tentatively proposed that ohiro is the abbreviated form of 'ohirohiro 'waterspout', which would be an apt description for the turbulent waves below Orongo. Lying on the small strip of rocks at the foot of Rano Kau, the victim was positioned immediately "behind" the breakers.

4) ka u'uri nō: The word uri 'dark, black' is also used to describe severely bruised skin (Fuentes 1960: 878: ‘bruised'; Englert 1978: 279: ‘black and blue').

6) 'i tu'a i te 'ōhiro (R: itua ohiro; Br: tuao iti ohiro; M1: itúáo l tě ó hiro; M2, Ba: tuao i te ohiro): The confusion about this phrase has led to the introduction of another seabird, the tuao. In M2 it is glossed as 'black rock-dwelling bird' [pajaro negro de roca]. Barthel translates the phrase as "tuao bird in Te Ohiro", but in a later publication he identified the bird as Anous stolidus unicolor (the brown or common noddy) (Barthel 1974: 169) and changed the interpretation of ohiro to "new moon" (p. 172). 
7) ka vara tayi nō: As Routledge has kavária tágne nó, an alternative possibility is vari in the meaning of 'to circle round'. However, in all later versions the verb is preceded by rava 'very' - a variant of vara.

All translations interpret tayi as 'to weep' or 'to mourn', but the word can also mean 'to scream, to wail, to groan'. As such it is also applied to the sounds of animals (e.g., Roussel 1908: 219: 'to mew'; 227: 'to squeal').

8) māhaki te makohe: The frigatebird is - perhaps ironically — called a "companion" because it has followed the egg hunter all the way from Motu Nui to the mainland. Alternatively, as māhaki can also be translated as "colleague" (see Englert 1980: 50-51), it may be an allusion to the correspondence between an egg thief and a bird species known for its preying on the eggs of other seabirds.

9-10) pariyi te matavai 'o te tu 'aivi kari i te hope (R: párigni te mátavái $\mid$ o te túavi | kariti te hupé; M1: kárítĭ tě húpee; M2: parini te hupee; Ba: ka riti te hupee): In R the word túavi is explained as 'a bird', mátavái as 'tears', kariti as 'streams' and hupé as 'nostrils'. The contractions show that the last part was thought to be more or less equivalent with parini te matavai 'to shed tears'. Métraux (NB 5rb: 9; NB 7: 48), for example, translates both parini te hupee and ka riti te hupe as 'to blow the nose'. This was probably deduced from the supposed presence of hupe ' $e$ 'nasal discharge'. The problem is that the word riti or kariti does not appear as such in the vocabularies. If, however, túavi is read as tu 'aivi 'back, spine, shoulder', and the frequently occurring alternation of vowels $o$ and $u$ in speech and notation is taken into account, it can be hypothesised that hupee originally was hope 'spine, backbone'. As a result, kariti can be explained as a contraction of kari i te (see Fuentes 1960: 756: karikari 'cut, incision'; Tregear 1891: 130: Māori kari 'maimed'; karikari 'to strip off'; Mangarevan kari 'scar').

Remarkably, the verses as recorded by Routledge resurfaced in their original order in the version of Felbermayer (1972: 277): Ka paringi te matavai ote Tuví / Ka kariti te hupe'e ote Kukuru toua. In Das Achte Land, Barthel (1974: 169) published a fragment of the text in which paringi te matavai is inserted wrongly after kariti te hupe 'e. Apparently, the error resulted from the fact that it was taken from Campbell (1971: 404) whose version lacks the latter line.

11-13) 'o te kukuru toua eve pe'epe'e pe 'epe'e 'à ure motu nui: The name and species of the bird which Barthel gives as "yellowish kukuru bird with the very short tail" has caused some problems. Apart from the islet's name this part of the text was left unexplained to Routledge (1914-15: Reel 2, 0683). Métraux collected both kukuru toua (NB 3: 3) and kukuru touo (NB 5b: 9) and noted for kukuru toua 'bird species' and for eve pepepepe 'not very prominent behind' [derrière peu 
proéminent] (NB 7: 48). Englert ([1948] 1974: 209) also lists the kukura toua as an unspecified seabird. In his later publication, Barthel (1974: 170) suggests the yellow-nosed albatross (Diomedea chlororhynchos) with kukuru 'handle' and toua 'yellow' describing the peculiar shape and yellow colour of the beak, and eve pepepepe 'with short tail' as an accurate observation of the species's relatively short tail feathers. He points out that the bird's name and the term for "short tail" also appear in the recitations that were improvised in 1873 by a Rapanui islander named Metoro to three Rapanui tablets inscribed with rongorongo in the possession of Bishop Jaussen of Tahiti.

The main problem with Barthel's identification is the second part of the epithet since the meaning 'short' for pepe or pepepepe is not found in any Eastern Polynesian vocabulary. In Metoro's "readings" of the inscriptions - in a Rapanui idiom heavily influenced by Tahitian - the word pepepepe appears in three segments (Barthel 1958: 177, 180, 188). In two of these, the bird occurs as kukurutou (pp. 177, 188), but only in one pepepepe is preceded by eve: kua hura te tagata / tona hura i roto i te pa / eaha te huri / o te manu kukurutou / ko te manu eve pepepepe (p. 188).

A comparison of Metoro's recitation with the corresponding glyphs on tablet Tahua as transcribed in Barthel (1958) (Fig. 1) clarifies what this means: "The man uses a sling. His slinging stone is in that circle (lit. 'enclosure'). Why does (he) throw (it)? Because of that kukurutou bird!" This suggests that the last part indeed could be translated as "It is the bird with the short tail".

However, in a similar bird-hunting scene on tablet Aruku Kurenga pepepepe clearly is a verb while eve is missing (Fig. 2). The context shows that pepepepe would make more sense if it is interpreted as 'to be exhausted': kua rere te manu / vae oho / ku pepepepe te manu kukurutou / kua mau ïa ki to vero: "The bird flees. (Its) feet are running. The kukurutou bird is exhausted. He impales (lit. 'fastens to') (it) on this spear". This suggests that pepepepe is a reduplication of Rapanui pe 'epe 'e '(to feel) tired, worn out, maltreated' (Fuentes 1960: 290; Englert 1978: 224).

This is confirmed by the third occurrence of pepepepe on the same tablet. The segment has a similar meaning, but here the kukurutou is absent (Fig. 3): ko te tagata itiiti mau rima ra / eaha te manu iti pepepepe mau i te hokohuki: "The little man raises (his) hand. Why does (he) maltreat the little bird, impaling (it) on the lance?"

As Barthel's suggestion of "short" for pepepepe does not make much sense in two of the three contexts, it seems likely that in the first fragment ko te manu eve pepepepe should be translated as "It is the bird with the maltreated behind". This would mean that it is used in a very similar 


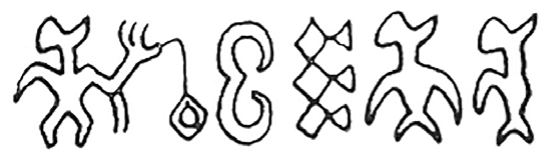

kua hura te tagata - eaha te huri - o te manu ko te manu tona hura i roto i te pa kukurutou - eve pepepepe

Figure 1. Fragment of tablet Tahua, side a, line 5.

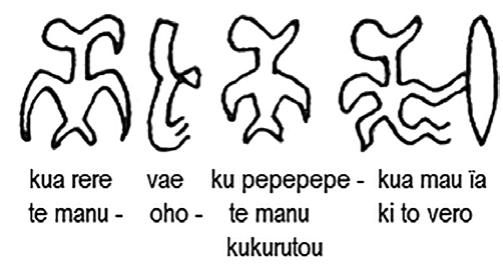

Figure 2. Fragment of tablet Aruku Kurenga, verso side, line 1.

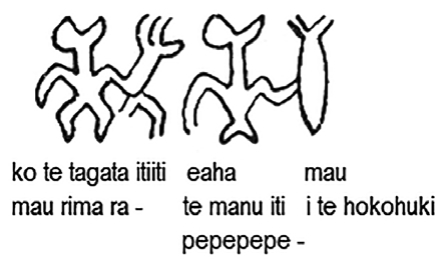

Figure 3. Fragment of tablet Aruku Kurenga, verso side, line 9.

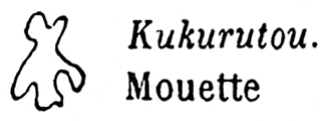

Figure 4. Detail of the "Jaussen list" (Chauvet 1935: fig. 137). 
way as in the chant under consideration, the only difference being the exchange of roles: the "maltreated behind" is that of the unfortunate egg hunter who has been under attack from an infuriated kukuru toua bird. That the protagonist himself is the owner of the buttocks in question is supported by the presence of ure in the next line. If this is simply translated as "penis" instead of Barthel's unattested place name UreMotu-Nui, the ingenuity of the text is revealed: whereas the climber's back has suffered from the fury of the aggressive birds, his front side has been exposed to the sharp rocks of Motu Nui.

One intriguing question that remains is why Metoro associated the term pepepepe exclusively with birds. A possible answer is that he was familiar with the song under discussion. His references to other texts such as the Atua Mata Riri chant and the legend of Hotu Matu'a certainly suggest that he had a broad selection of traditional material at his disposal. If he knew the meaning of pe 'epe' $e$ and had some general understanding of the chant, this would explain his use of the word in the context of confrontations with birds as well as his use of the specific term eve pepepepe in connection with the kukurutou.

With the "short tail" no longer available for determination, the identification of the kukuru toua as an albatross also becomes uncertain. Interestingly, the so-called "Jaussen list", which was compiled from Metoro's recitations, translates the name as "seagull" [mouette] (Fig. 4). This may well be correct as some of the species are quite large and many of them sport yellow bills. Another complicating factor is that toua could have another meaning than 'yellow'. Roussel (1908: 181), for example, has toua as a variant of tau ' $a$ 'to fight, battle, enemy'.

14) etoru haye rā: The "threesome" referred to consists of the two birds makohe and kukuru toua and the islet of Motu Nui. Englert (1978: 119) gives haye (and hayehaye) as 'to outdo, to surpass'. An alternative interpretation could be etoru aya rā 'Did those three cause (this)?'

15) ka kai to koro pera: The word pera describes the three islets as taboo locations and/or graveyards (see Roussel 1908: 231: 'to forbid'; Englert 1978: 225: 'cemetery, taboo place').

16-18) motu nui motu 'iti motu kaokao: Returning from Motu Nui, a swimmer would first pass Motu Iti and then Motu Kaokao (Fig. 5). Only Barthel's version has the islets arranged in this order.

19-20) kai tu' 'u mai koe e papa rona rakerake é: Routledge has kai ta ui mai koe ma púku rákeráke, with ta ui mai koe glossed as 'you will not see'. Assuming that the first part is a mistake for kai tu 'u mai koe, this could be translated as "You were not reached with (your) wretched peaks" (Englert 1978: 234: puku 'peak'). This means that in her version "you" 


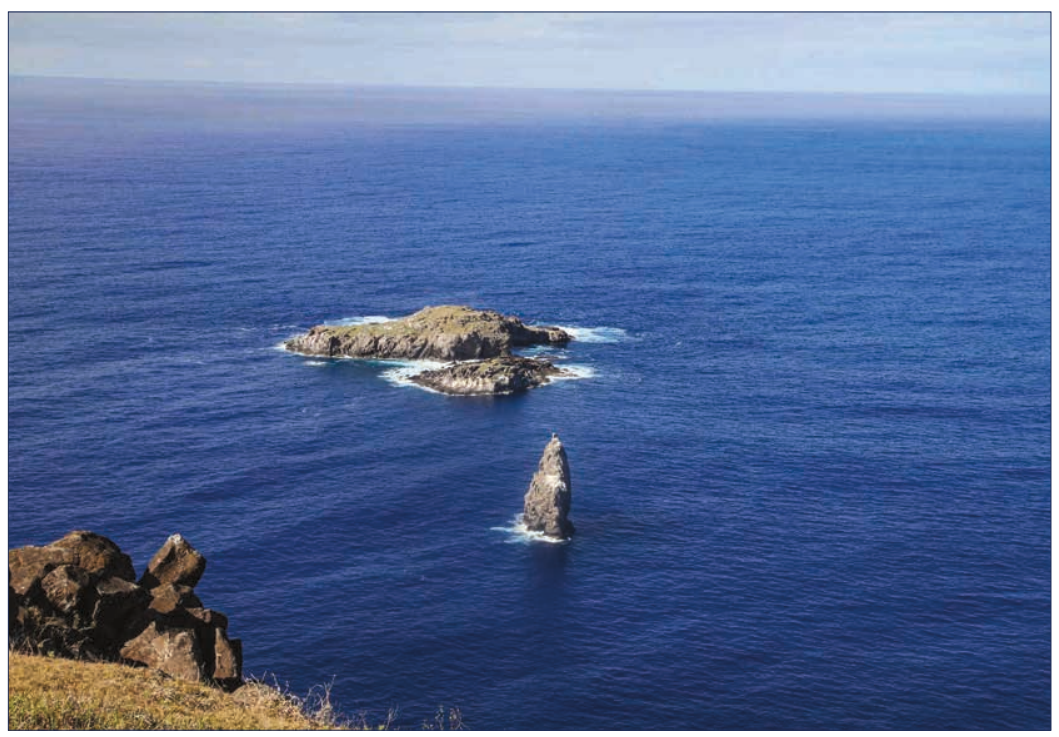

Figure 5. View from Orongo (left) towards Motu Kaokao, Motu Iti and Motu Nui, respectively. https://www.flickr.com/photos/travel aficionado/6602357797/sizes/o/ (detail); Creative Commons license: https://creativecommons.org/licenses/by-nc/2.0/

refers to Orongo as the place of destination, whereas in the others the "sculptured rock" is addressed. In both variants, the destination is designated as the deictic centre of the phrase by the directional particle mai (see Kieviet 2017: 351-52).

Although Routledge's version suggests otherwise, it is tempting to translate the sentence as " $(\mathrm{He})$ did not reach that wretched sculptured rock" (for the third person interpretation of the construction koe e ... $\bar{e}$, see Kieviet 2017: 145).

21-22) vae pahu era e ki tā 'aku papaku: See Roussel (1908: 184): pahu papaku 'coffin'.

23-24) he uha 'uri ta papaku 'uri (R: hé úha kúri ta pápákúri; M1: héuha kurí / tá papa kurí M2: he uha kuri ta papaku kurí). The fieldnotes of Routledge and Métraux show that the glottal stop of 'uri had changed into $/ \mathrm{k} /$ and that the word was interpreted as kuri 'cat', an animal unknown to pre-contact Rapa Nui. Barthel (1960: 855, n50) remarks that this was also how it was recited to him. 
25-26) uha mea 'iti' 'iti to te 'ata ōma: The last part, rendered as totehátá uma $(\mathrm{R})$, tóte hataúma (M1), to te hataura (M2) and to te hatauma (Ba), is difficult to explain. Métraux (NB 5rb: 9) notes "chicken brochette" [brochet de poulet] for hatauma while Barthel suggests "corpse lying in state" [Aufbahrung]. However, if the term is assumed to be more or less equivalent to the "bruised corpse" in line 24 , it can be read as "ata óma 'disfleshed shadow'. In Polynesia, 'ata 'shadow, image, reflection' was also applied to animals or objects incarnated by gods or other supernatural beings. The term may have been used here to denote that the body of the deceased had hitherto functioned as a receptacle for the spirit. Interpreted as oma 'emaciated' (Englert 1978: 213: ömaōma 'emaciated'), the second term could then allude to the condition of the corpse - "disfleshed" by birds and rocks - as well as to the appearance of the spirit — on Rapa Nui, the spirits of the dead were imagined as emaciated corpses.

Barthel (1960: 855-56) interprets $u$ ha literally as 'hen', pointing to the tradition that five cocks were tied to each of a deceased birdman's feet. However, the text does not speak of cocks but of hens, and does not give a number. Furthermore, the word $u$ ha was also commonly used to refer to women (Englert [1948] 1974: 37). An important argument for this figurative interpretation is that all versions have possessive $t a$ referring to the first "hen" and possessive to to the second. Barthel's interpretation does not account for this difference. It could, however, be explained if it is assumed that the deceased was both married and involved in an extramarital relationship as spouses are ' $a$-possessed (alienable) whereas friends are $o$-possessed (inalienable) (see Kieviet 2017: 296-97).

The term "hen" for the two fondly remembered women may have been specifically chosen to contrast them with the two hostile birds in the first part of the chant.

27) he naunau nō: Sandalwood used to grow on the steep slopes of the coast (Englert 1978: 206). The tree disappeared from the island in the 1880s (Métraux 1940: 17-18). Several traditions attribute magical properties to this wood, which was highly valued for its fragrance (e.g., Brown 1924: 148; Routledge 1919: 243, 262).

29-30) he 'óroyo nō/ta puku 'óroyo: An alternative interpretation is "Orongo will always be here, (he) will remain part of the rocks of Orongo". These lines only appear in Routledge's version.

33-34) he retu nō / ta hü hatu retu: The word retu is explained as 'tattoo on the head' by Roussel (1908: 246). The term hatu means 'big lump' or 'compact mass' (e.g., Englert 1978: 125: hatu matá 'piece of obsidian'). The term is preceded by the demonstrative determiner $h \bar{u}$ indicating that the referent, the "tattooed" boulder, has been mentioned previously. 
This suggests that it is identical with the "sculptured rock" of Orongo in line 20. In the modern language the marker is always accompanied by a postnominal component, either a demonstrative (ena, era, nei) or an identity marker ( 'á,' 'ana) (Kieviet 2017: 195).

35) he tahoya nō: The tahoya is an ovoid, usually wooden pendant which is mentioned in different ritual contexts. During an initiation ceremony for children which usually took place at Orongo, the so-called poki manu 'bird children' wore tahoya in pairs on their back (see Routledge 1919: 267, fig. 114). They are also mentioned as part of the king Nga'ara's regalia (Englert [1948] 1974: 42). Orliac and Orliac (2008: 197-98) suggest that the tahoya represents the sacred egg of the birdman ritual, arguing that the fine ridges in low relief that divide the hanger into three or four equal parts indicate the strings by which the egg was suspended in the house of the birdman near Rano Raraku. Routledge (1919: 262) notes that the bird egg was transported in a "little basket" that was tied round the forehead. Another tradition states that a pumpkin ( $k a h a)$ was used (Englert 1980: 200). The presence of an object called tahoya among the hopu manu's possessions opens the possibility that it originally was a simple net or small basket. As the bearer would have been lying on a reed float (pora) during the swim, it would likely have hung on his back. That it may have served as a container for precious contents is perhaps also indicated by its name, which may be cognate with Māori taonga 'property, treasure' (Tregear 1891: 468).

40) ko haho ko te va'ai vaka: Ko haho is an abbreviation of ko haho ko te tai 'out on the sea'.

41) ta koro pāoa mau: The fact that the term paoa is used for the club suggests that the father had a special function. The guards of the tribe in power-i.e., the tribe that supplied the birdman-were called tajata paoa or simply paoa after the clubs they carried (Englert [1948] 1974: $103 ; 1978: 220)$. As such, the father was apparently involved in the rituals of the birdman cult: in line 48 he takes part in the ceremonial dancing and in line 50 he is described as carrying the birdman.

44) ko te yatu 'a huri reya: In an agricultural context, the verb yatu 'to press, to squeeze, to tighten' is used for the planting of shoots, etc. (see Englert 1978: 113: he-yatu te rau 'to press shoots into the soil'). The term may actually be yatua - a variant given by Englert.

According to Fuentes (1960: 747), in old times the word huri 'banana shoot' simply meant 'sprout', to which the name of a specific plant was added. As the shoots in this line are from the sugarcane whereas in line 53 they belong to the sweet potato, it is proposed that reya is an obsolete term for 'yellow', referring to the light colour of sprouts and new leaves. This colour term occurs in several Polynesian languages and derives from renga, the general name for the turmeric 
(Curcuma longa), the source of a yellow or orange dye. As such it was also known on Rapa Nui (Métraux 1940: 236).

47) ko raro ko te paena: The traditional boat-shaped houses were called hare vaka 'boat house' or hare paena after the foundation stones that were laid in an elliptic groundplan. Each paeya had two or more holes to support the framework of the thatched roof.

48) ta koro papa hiki kauya: Ritual dances were an important part of Rapanui ceremony and were also performed during the birdman ritual (Routledge 1919: 259, 263). However, the kauya or hikiya kauya ceremony and the dance called hikina kauja are generally considered to have been part of the initiation rites of secluded children (see Métraux 1940: 350; Englert [1948] 1974: 163, 229-30). For Barthel (1960: 856), this was one of the reasons to suspect an initiation motif in the chant, despite the fact that the text clearly states that it is the father who is partaking in the dance. Moreover, there is nothing in the term hiki(ya) kauya to suggest that it was performed exclusively by children at their initiation ceremony: hiki means 'to flex the knees' (Englert 1978: 131) and kauja 'to line up' (see Roussel 1908: 193: kauga, hakakanga 'two by two'; 176; 191: hakakauga 'to align, in file'). Routledge (1914-15: Reel 2, 0816) was told that the dance was also performed by adults and on different occasions, such as the celebration of a victory or the feast given in honour of a mother. Brown (1924: 201) supports this by describing it as "dancing in file, one woman followed by one man in a long row". In the chant, the addition of papa refers to the fact that the dance was performed on paths of flat stones (papa). These dancing grounds were also called kauna (Routledge 1919: 234).

In the reconstruction, the initial possessive-which is to in all versions - has been changed to $t a$ to correspond to the other activities of the father. Possibly, this to was caused by the interpretation of koro as 'ceremony' "the hiki kauna dance was part of the ceremony").

59-60) ko te ehuehu / ko te kapuapua: These lines may have been stock phrases for the ending of poetic texts as they also appear in the final part of the Apai recitation collected by Thomson (1891: 518) and at the end of a short chant published by Barthel (1960: 842). In the Apai chant, the "smoke" and "fog" are the clouds into which the daughter of Tangaroa disappears on her way to the sky (see De Laat 2014: 30). Here, they refer to the steam from the earth oven that is starting to blur the recollections of the past life - a poignant illustration of the severance of the last bonds connecting the spirit to the body. As kapua also means 'to be covered with moss' and ehuehu also 'ashes, dust', the imagery may also include allusions to the physical decay of the body. 
In this paper a popular Rapanui string figure chant has been reinterpreted in the context of the annual egg hunt of the birdman ritual. As such it has emerged as a vivid and surprisingly lyrical variation on the universal motif of life flashing before a dying person's eyes. In its Rapanui guise, fragments of an unfortunate contender's past are relived by his spirit as it is in the process of detaching itself from the dead body. The text appears as a coherent narrative that first gives an account of the events that have led to the young man's death and then dwells on the cherished memories of the life that he has left behind.

If the results of the approach proposed in this paper prove to be valid, they would constitute an improvement on previous interpretations that consist of garbled collections of only partly comprehensible verses. There would be no lines that have to remain unexplained because they are supposedly written in an unknown ancient idiom or require access to some arcane knowledge. On the contrary, with its clear, concise language, its evocative imagery and its display of authentic emotion, the chant would stand as a remarkable example of the level of sophistication of pre-missionary Rapanui literature.

To illustrate the latter, the text can be analysed as an intricate pattern of contrasted and repeated elements. In the opening lines, the red of the (bloody) loincloth and the "black and blue" of the bruised body of the hори тапи are reflected in the red gular pouch and the black feathers of his "companion", the frigatebird. Further on, the same colours return in the dark and ruddy complexions of the two girls - the lovingly remembered "hens" that are contrasted with the two aggressive seabirds. And finally, the colours establish a link with the newly elected birdman who will return triumphantly from Orongo with his face painted in red and black (Métraux 1940: 337). The red and the black in turn are contrasted with the white colour of the "pale" corpse and the plumage of the kukuru toua-likely a seagull or albatross - and the white tern.

Stones and rocks are another important motif in this play with analogous and opposite images. The sharp beaks and claws of the birds are juxtaposed to the jagged rocks of the three offshore islets. The precise arrangement of the carefully hewn paeya stones of the protagonist's paternal home is contrasted to the disorderly heaps of rock below Orongo that have become his final resting place. The father who has laid these foundation stones is compared to the man who is ritually dancing on "flat stones". The "tattooed"-i.e., sculptured-boulders of Orongo where he is performing are connected to his dead son through the tattoo on the latter's forehead. Possibly, the author intended the father to emerge as the real tragic figure of the story. He has sent his son into the service of a candidate birdman and can therefore be held responsible for his death. And while he will probably be unable to bring his son's body home, he seems to be part of a group of men who are tasked with carrying the victorious birdman back from Orongo. 
It could be argued that the complexity of the chant and the disappearance of the traditional culture have facilitated the gradual loss of meaning that resulted in a largely misunderstood text. This likely happened in the time period after the 1860 s when the birdman cult was abandoned and the majority of the population perished through slave raids and diseases. It is not difficult to imagine that once the main theme was no longer fully comprehended the tightly structured narrative could easily have disintegrated into a collection of cryptic and unrelated fragments.

Several Rapanui manuscripts that have surfaced in the twentieth and twenty-first centuries suggest that the inquiries of researchers such as Thomson, Geiseler, Knoche and Routledge sparked the interest of literate natives to preserve their cultural heritage by recording - and sometimes reconstructing - the remains of the rapidly disappearing traditions. It could be hypothesised that someone with an intimate knowledge of Rapanui language and culture would have been able to compose a chant of this type in the post-missionary period, incorporating perhaps fragments of older texts. There is, however, one notable obstacle to this scenario. If the chant had been manufactured in the late nineteenth or early twentieth century, it would be difficult to explain how its meaning could already have been largely forgotten when Routledge recorded it in 1914. It seems therefore far more plausible that the chant is a pre-missionary text dating from a time when the birdman cult was still in full flower. The fact that it continued to be performed as a string figure recitation long after the demise of this institution may have contributed substantially to its survival.

Apart from the presence of a number of obsolete words and archaic expressions, there are three-perhaps four - circumstances that point to an ancient provenance of the text:

1. Barthel (1960: 856-57) notes that the chant's vocabulary has remained free of Tahitian influence. This influence started in the 1880s with the return of Rapanui from Tahiti and the arrival of Tahitian catechists and labourers (Kieviet 2017: 16).

2. The recitations of Metoro suggest a familiarity with the chant. According to Fischer (1997: 49), these were probably recorded in August 1873.

3. The description of the attack by the frigatebird and the kukuru toua has the appearance of an authentic detail. Their unusual aggressive behaviour can only have been the result of a direct threat to their nests. However, the fact that in the final stage of the birdman competition the egg of the sooty tern had become the sacred object indicates that the frigatebird had stopped nesting on Motu Nui before the 1860s. Although the bird could still be seen soaring above the island's fishing grounds, it laid its eggs on the Juan Fernández Islands - some 2,800 km away. 
4. The origin and function of the ceremonial tahoya pendant were no longer remembered in post-missionary times. If it was present among the hopu manu's possessions because it originated as a net or protective carrier for the bird egg, this would be another indication of the chant's antiquity.

In all, these arguments establish with reasonable certainty that the chant dates back to at least the $1860 \mathrm{~s}$ - and possibly to a period well before that time. This means that this remarkable specimen of traditional Rapanui literature bears witness to the fact that orally transmitted texts can survive relatively intact even when much of their meaning is no longer understood. Hopefully, this study has shown that once seemingly cryptic texts are placed in their proper context, they may reveal themselves as perfectly coherent narratives. In my opinion, there is a substantial corpus of traditional Rapanui texts - both published and unpublished - that have been dismissed too easily as inaccessible or that have not yet received proper scholarly attention.

\section{ACKNOWLEDGEMENTS}

I would like to express my sincere thanks to Christopher Browder and Paulus Kieviet for generously providing some of the source material, to Angeli Broekhuijsen for her meticulous review of the text and to the referees for their comments.

\section{NOTES}

1. All English translations from Rapanui, French, German and Spanish sources are the responsibility of the author.

\section{REFERENCES}

Barthel, Thomas S., 1958. Grundlagen zur Entzifferung der Osterinselschrift. Hamburg: Cram, de Gruyter \& Co.

1960. Rezitationen von der Osterinsel. Anthropos 55 (5/6): 841-59.

_ 1974. Das Achte Land. Munich: Klaus Renner Verlag.

Bierbach, Annette and Horst Cain, 1993. The Rapanui pantheon. In S.R. Fischer (ed.), Easter Island Studies: Contributions to the History of Rapanui in Memory of William T. Mulloy. Oxford: Oxbow Books, pp. 133-37.

Blixen, Olaf, 1979. Figuras de hilo tradicionales de la Isla de Pascua y sus correspondientes salmodias. Moana, Estudios de Antropología Oceánica 2 (1): $1-106$.

Brown, John MacMillan, 1924. The Riddle of the Pacific. London: T. Fisher Unwin Ltd. Campbell, Ramón, 1971. La herencia musical de Rapanui: Etnomusicología de la Isla de Pascua. Santiago de Chile: Andrés Bello.

Chauvet, Stéphen, 1935. L'île de Pâques et ses mystères. Paris: Éditions "Tel”. 
de Laat, M., 2014. Ascension: Proposal for a reconstruction of Ure Vaeiko's Apai recitation. Rapa Nui Journal 28 (1): 23-37.

Englert, Sebastian, [1948] 1974. La tierra de Hotu Matu'a: Historia, etnología y lengua de la Isla de Pascua. Santiago: Editorial Universitaria.

-1978. Idioma Rapanui: Gramática y diccionario del antigua idioma de la Isla de Pascua. Santiago: Ediciones de la Universidad de Chile.

1980. Leyendas de Isla de Pascua: Textos bilingües. Santiago: Ediciones de la Universidad de Chile.

Felbermayer, Fritz, 1972. Lieder und Verse der Oster-Insel. Zeitschrift für Ethnologie 97 (2): 270-85.

Fischer, Steven Roger, 1997. Rongorongo: The Easter Island Script; History, Traditions, Texts. Oxford: Clarendon Press.

Fuentes, Jordi, 1960. Diccionario y gramática de la lengua de la Isla de Pascua / Dictionary \& Grammar of the Easter Island Language. Santiago: Andrés Bello.

Kieviet, Paulus, 2017. A Grammar of Rapa Nui. Berlin: Language Science Press.

McCall, Grant, 2006. Book reviews. The Australian Journal of Anthropology 17 (2): 250-52.

Métraux, Alfred, 1934-35. Fieldnotes of the 1934-35 Franco-Belgian Expedition (10 notebooks). Völkerkundliches Institut der Universität Tübingen.

-1940. Ethnology of Easter Island. Bernice P. Bishop Museum Bulletin 160. Honolulu.

Mulloy, Emily Ross and Sergio Alejo Rapu, 1977. Possession, dependence and responsibility in the Rapanui language. Journal of the Polynesian Society 86 (1): 7-25.

Orliac, Catherine and Michel Orliac, 2008. Trésors de l'Ile de Pâques / Treasures of Easter Island. Paris: Éditions Louise Leiris / Éditions D.

Roussel, Hippolyte, 1908. Vocabulaire de la langue de l'Ile-de-Pâques ou Rapanui. Le Muséon 27: 159-254.

Routledge, Katherine, 1914-15. Papers of Mrs. Katherine Scoresby Routledge relating chiefly to Easter Island. Royal Geographical Society, London. Microfilm at the Pacific Manuscripts Bureau, Australian National University, Canberra (PMB 531, Reels 1-4).

1919. The Mystery of Easter Island: The Story of an Expedition. London: Hazell, Watson and Viney.

Thomson, William J., 1891. Te Pito te Henua, or Easter Island. Report of the United States National Museum for the Year Ending June 30, 1889. Annual Reports of the Smithsonian Institution for 1889. Washington, pp. 447-552.

Tregear, Edward, 1891. The Maori-Polynesian Comparative Dictionary. Wellington: Lyon and Blair.

Van Tilburg, Jo Anne, 2003. Among Stone Giants: The Life of Katherine Routledge and Her Remarkable Expedition to Easter Island. New York: Simon \& Schuster.

\section{AUTHOR CONTACT DETAILS}

Mary de Laat. Email: marydelaat@planet.nl 
